\title{
Re(thinking) Critical Language Education with Children and Teacher Education During (and After) Pandemic Times
}

\section{Re(pensando) educação linguística crítica com crianças e a formação de professores/as durante (e depois) da pandemia}

\author{
Claudia Jotto Kawachi-Furlan* \\ *Universidade Federal do Espírito Santo (UFES), Vitória, Espírito Santo / Brasil \\ claudiakawachi@gmail.com \\ https://orcid.org/0000-0003-4699-6774 \\ Juliana Reichert Assunção Tonelli** \\ **Universidade Estadual de Londrina (UEL), Londrina, Paraná / Brasil \\ jtonelli@uel.br \\ https://orcid.org/0000-0001-5102-5847
}

\begin{abstract}
The aim of this article is to discuss teachers' perspectives on how the COVID-19 pandemic has impacted the teaching of English to young learners (TEYL). We focused on one specific question (from a 10-question online questionnaire) in which participants shared their thoughts, experiences and concerns about TEYL in pandemic times. The answers were analyzed in a qualitative perspective, based on critical literacy research and studies in the field of TEYL. The results indicate the participants' exhaustion due to dealing with unusual situations, and teaching focused exclusively on content in an attempt to show how teachers are reinventing themselves despite uncertainties and lack of training. The present moment requires reflections about goals and expectations in TEYL and in teacher education.
\end{abstract}

KEYWORDS: English language; children; COVID-19 pandemic; teacher education.

RESUMO: O objetivo deste artigo é discutir as perspectivas de docentes sobre como a COVID-19 tem impactado o ensino de língua inglesa para crianças (LIC). Focalizamos as análises em uma questão específica (de um questionário composto por 10 itens) na qual os/as participantes compartilharam pensamentos, experiências e preocupações sobre ensinar LIC durante a pandemia. As respostas foram analisadas qualitativamente, com base em pesquisas sobre letramento crítico e estudos em LIC. Os resultados revelam 
a exaustão dos/as participantes decorrente de situações inusitadas e apontam ainda para um ensino focado exclusivamente em conteúdo em um esforço de mostrar como as/os professoras/es estão se reinventando, apesar de incertezas e ausência de formação. O momento atual demanda reflexões sobre os objetivos e as expectativas no ensino e na formação de professores/as de LIC.

PALAVRAS-CHAVE: língua inglesa; crianças; pandemia COVID 19; formação docente.

\section{Introduction}

The current pandemic times (COVID-19) caused by a previously uncharacterized virus have presented devastating psychological, physical, and emotional consequences to all of us. People across the entire world have been dealing with the effects of social isolation, associated with crises in health, economy, and education (YI; JANG, 2020). In this scenario where new social differences have become evident, language educators have been facing challenges related to the naturalization of inequalities, teacher exhaustion, and, sadly, death. Thus, it is our commitment to discuss our praxis as possibilities to fight against necropolitics and necropower in education (LIBERALI, 2020).

In the context of Teaching English to Young Learners (TEYL), it is even more complex, as this area struggles to consolidate itself as a possibility of educating through language with children, not only to children (MALTA, 2019; PINTER, 2019). Teaching children was challenging enough before COVID-19. This field has been thriving despite several issues that compromise teachers' practices and students' experiences, such as lack of laws that regulate how additional languages are offered in the early years of education in Brazil (ROCHA, 2006; ÁVILA; TONELLI, 2018) and also in some other regions of the world (MOURÃO, 2019), besides the fact that very few teacher education programs cover this context (MILLER et al., 2019).

In addition, neoliberalism has been explicitly exerting its influence upon TEYL as we witness the rapid increase in the number of bilingual (Portuguese and English) schools and programs, as well as language-specific and regular schools that offer English as a discipline in their curriculum with the promise that it will make a difference in students' lives. Certainly, we cannot deny that knowing an additional language grants many benefits and advantages in personal, academic, and professional domains. However, the 
question at hand is not the possibility of what language education represents, that is, a process in which people engage to construct meaning, as suggested by Jordão (2018); it is the widespread-and from our point of view, entirely false-idea in these programs that English is a product, functioning as a career booster or something that will be objectively important for the child's future.

In previous studies, researchers have discussed the myths involved in the assumptions of the prevalent discourse of "the sooner, the better" (CARVALHO; TONELLI, 2016; KAWACHI-FURLAN, ROSA, 2020). Educators need to be involved in this discussion in order to problematize these hegemonic discourses that naturalize how children learn additional languages and also to engage in the reflection of what we aim to accomplish and why we defend TEYL. In this sense, we advocate in favor of (critical) language education with children, as this proposal reassesses what teaching and learning an additional language means, considering sociocultural dimensions, as suggested by Ferraz and Nascimento (2019).

Pandemic times, however, have challenged the appreciation built around language education with children; our data shows a return to traditional practices that focus solely on teaching grammar and vocabulary, relying on a structural perspective of language. In order to cope with the system that we live in, or as Ferraz (2020) calls, "the mechanism", teachers go back to what is considered safe ground (teaching isolated linguistic items) and to what can be measured (and sometimes controlled) by parents and school administrators. All the while, we see financially privileged children trapped into a screen with remote, online classes that may not be relevant to them; and at the same time, children from low socioeconomic backgrounds are left without shelter, food or care, let alone English classes.

The aim of this article ${ }^{1}$ is to discuss teachers' perspectives on the impacts of the COVID-19 pandemic in teaching English to young learners. ${ }^{2}$ At the beginning of the pandemic in Brazil, we invited teachers of English to children to respond to an online questionnaire about teaching during

\footnotetext{
${ }^{1}$ This paper is part of the postdoctoral research developed by the first author under the supervision of the second. Taking into consideration ethical issues of coauthoring, we state that this article was co-constructed by both authors based on reflections built during this period of study.

${ }^{2}$ Although we advocate English with and not only to children, we understand that this is how the area is widely known.
} 
pandemic times. The questionnaire, composed of 10 questions, was answered by 62 teachers and, in this study, we will focus on one specific question as detailed ahead. In addition, participants were also invited to attend a virtual meeting to discuss the topic of the questionnaire, sharing their thoughts and concerns, as well as reflecting about researchers' views on what had been observed in participants' answers.

To meet what is expected in this genre, the paper is organized in sections; however, all items are related, as they are connected to the authors' reflections about teachers' perspectives of TEYL during the pandemic. Thus, following this introduction, an outline of the study and its collaborators are presented in the next section, followed by a discussion on how the pandemic contributed to a focus on traditional practices and the need to re-educate ourselves to consider praxis focused on children's contexts, expanding our understanding of teacher education.

\section{Presenting the study and the collaborators ${ }^{3}$}

As both teachers and teacher educators, we have been deeply concerned as we follow both the young learners having English classes at home (those who have this chance), as well as their teachers who have carried out their duties, putting aside their emotions, needs, mental and physical health and, last but not least, their standard practices. In this section, we provide an overview of the research and present the teachers ${ }^{4}$ who participated by sharing their opinions, thoughts, and feelings.

In this qualitative study (LÜDKE; ANDRÉ, 2017), we aim to interpret and discuss the data generated in the light of specialized theory from critical literacies, TEYL and the education of English teachers.

In the following sections, we intertwine the voices of the participants together with the ideas of other authors to establish a dialogue. By not following the traditional linearity in presenting theory followed by data, we seek to bring the dialogues established closer together, discussing the

\footnotetext{
${ }^{3}$ As this research involves human beings, the project that originated this study was submitted to the Ethics Committee and approved on $07 / 13 / 2020$, under the number CAAE 33755020.3.0000.5231.

${ }^{4}$ We use the terms collaborators and participants as synonyms to refer to the teachers who answered the questionnaire.
} 
teachers' perspectives of their educational praxis during the COVID-19 pandemic.

To better understand the participating teachers, among other actions, we promoted virtual meetings to talk about TEYL and prepared a questionnaire to learn more about those who were/are dealing with such unprecedented situations. This questionnaire ${ }^{5}$ was the source of the data analyzed in the present study. The questionnaire itself was composed of 10 questions and was sent by email and shared by social media in groups of teachers, mainly WhatsApp and Facebook communities. The first four items aimed at outlining the participants' profile: an alias, age, gender and educational level. Question number five asked the respondents to indicate their teaching context; question six asked for the city and state where they teach. The seventh question, a close-ended question, sought to know if participants were, at that time, teaching remotely; depending on their answer, they were asked to share, in question 8, their personal thoughts on whether the absence of English classes would be detrimental to the students' education.

The great majority of the participants were between 20 and 40 years old and identified as women (90,3\%); only 9,7\% identified as men. With reference to participants' educational level, the largest group of respondents held a Master's degree and/or other specialization, representing 40\% of participants. Approximately 33\% held a bachelor's degree or equivalent in Languages and Literature, and approximately 5\% in Pedagogy.

Regarding the teaching context, most respondents said that they work either at private schools teaching kindergarten $(38,7 \%)$ or with lower, primary grades at public schools $(37,1 \%)$.

Taking into consideration that the questionnaire was delivered to TEYL exclusively working in the Brazilian territory, the responses to the sixth question showed that the collaborators teach across many different regions of the country, specially the South, Southeast and Midwest.

The ninth item, whose answers are the focus of the analyses in this paper, asked the participants what they would write if they had a chance to publish a brief text on social media sharing their experiences, worries and complaints about TEYL in pandemic times.

\footnotetext{
${ }^{5}$ The questionnaire and its answers were originally written in Portuguese and the extracts from participants' answers were translated to English.
} 
The last item on the questionnaire wished to know if the teachers would like to take part in a closed community on Facebook to share their thoughts and feelings with other teachers about the issue. As for this matter, it is important to say that although many of them $(71 \%)$ presented an interest to be involved in the social media community, we felt the need to have a different space to listen to them. As such, later on, we invited the participants for an online talk, during which they had the opportunity to interact with the authors of this article and with each other and discuss the theme of this study.

\section{Have the pandemic times contributed to reinforce traditional practices in TEYL?}

In this section, we focus on research that can help us to discuss teachers' perspectives on the impacts of the COVID-19 pandemic on teaching English to young learners, giving special attention to the possibilities and limitations related to teacher education and its connection with language education.

As extensively discussed by Brazilian researchers (ROCHA, 2006; CHAGURI; TONELLI, 2012; TANACA, 2017; ÁVILA; TONELLI, 2018), there is a lack of laws regulating how additional languages are offered and implemented during the early years of education in Brazil, followed by the impact such a legislative void seems to be causing. In our view, this scenario contributes to the lack of understanding of what it really means to teach languages to children. At this point, some questions come to our minds. The first one is: Is it possible to focus on teachers' praxis highlighting students' realities?

\section{Excerpt 1:}

The pandemic arrived and no one was prepared. Teachers are not prepared to teach remotely. Unfortunately, we have "made it" with what we have and the way it is "possible". Children were also not prepared to face all of this and they need to adapt themselves by sitting in front of a computer for 2, 3, 4 hours a day to study, without having contact and interaction with their friends. However, children have surprised me in relation to learning in English, they are demonstrating development in English even without face-to-face classes. Maybe, If I had had, as a teacher, learned how to deal with children in a remote way, they would have learned more. 


\section{Excerpt 2:}

It is a huge challenge to reinvent the teaching of English in remote learning because in undergraduate and graduate courses this method has never been prioritized. In the current circumstances, it was necessary to study and research distance teaching methods, and the big dilemma for me was the exposure of my image, my voice on social networks, especially WhatsApp, the difficulty of recording videos, editing them and other necessary skills. Everything is so new that I am still in the "strangeness" phase. Trying to adapt myself to this new routine with a new way of teaching. For me, it is more complicated because I'm adapting myself to teach English language classes. I think the key word for the moment is "try". Try one method, try another and another. Until you find the one that best suits this new reality. Remember: writing and speaking in English are not the same.

Both teachers seem to highlight their attempts to continue teaching and to find new alternatives (expressed mainly by the verb 'reinvent') to carry out their tasks despite all the emotional, technological and physical barriers and difficulties. The emphasis on "trying" made by both participants seems to reinforce the fact that it does not matter if such an activity is carried out remotely or face-to-face, the teaching of English to children is-or rather, still is-a 'testing' process that may lead us to practices beyond the Freirean notion of praxis. This is due to the fact that this effort through trial and error seen in the excerpts does not consider children's needs, but instead seeks to please the schools they teach at to find a way not to stop, no matter what.

The participants' choice to use the verb "reinvent" to describe what they should do caught our attention, that, from their point of view, they are responsible for finding new ways ("invent again") regarding their teaching in the current situation. We agree with the teachers that, not only in moments of crisis but also on a daily basis, it is fundamental to change our actions in order to continue to be informed about what it means to be a language educator. What concerns us is the idea of reproducing common discourses that place the responsibility solely on teachers for any failure during the process. On the one hand, if learners face any type of difficulty, teachers are blamed for not having "reinvented" themselves sufficiently. On the other hand, when learners succeed, in most cases teachers are not acknowledged. It is our understanding that, in order to cope with the current scenario, teachers need help from their institutions, universities and the authorities responsible for this matter at the government level (such as the Brazilian 
Ministry of Education). It should not be an individual issue, as described in the following answers to the questionnaire:

\section{Excerpt 3:}

The point is that we live in a moment when the teacher needs to reinvent $\mathrm{him} /$ herself even though he/she is not prepared to produce videos of good quality to transmit the content to the students.

\section{Excerpt 4:}

The time has come to reinvent ourselves, to seek new methods so that students, even at a distance, may receive new knowledge. That is the way we are in this pandemic...

\section{Excerpt 5:}

I believe that as teachers, we have this capacity and condition to adapt and reinvent ourselves. Of course, during this period of anxiety and many concerns, without training and time (as a mother, wife, housewife, daughter, granddaughter and sister), the work is endless. But we have to understand that we are living in a unique moment, and that, not only teachers are reinventing themselves, but all professionals around the world. So get your lemons and add gin! Cheers!

Sayings such as these ("teacher needs to reinvent him/herself even though he/she is not prepared to produce videos of good quality"; "we have this capacity and condition to adapt and reinvent ourselves"; "we have to understand that we are living in a unique moment, and that, not only teachers are reinventing themselves") make it evident that teachers are focused on their individual responsibility in this process.

This perspective of emphasizing the individuals and their merits and/or failures is an effect of neoliberalism ideas. As suggested by Kubota (2016, p. 476), this "ideological and structural apparatus" creates individual accountability for success while it reduces State functions. Once more, we are aware of teachers' needs to frequently reinvent their practice; but this should be accompanied by questions and reflections throughout the process, as we find ourselves performing queries regularly about our roles as teachers, teacher educators and researchers. Robinson and Diaz (2005, p. 27) present the contributions of feminist poststructuralist views on individual subjects, considering them as "changing, contradictory, unstable, irrational and 
shifting across different contexts". To the authors, these subjects reinvent themselves "as they negotiate the various power relationships that exist in their lives" (p. 27).

As a result of neoliberalism influences, many participants vented their feelings of exhaustion, as it may be observed in excerpts 6, 7 and 8:

\section{Excerpt 6:}

At the beginning of the quarantine, when we still didn't know exactly what was coming, I saw teachers on their own, looking for how to use more common social networks, such as Facebook and WhatsApp as a way to continue to "teach" their students. Soon after, there was a great rush to the new Eldorado, that is, the conquest of one of the many digital platforms that promise, with its resources, the miracle of digital learning. I confess that I have not adapted myself to any of them, despite having to deal with this reality. I don't see any of these tools replacing classroom interaction. In addition, the tiredness and stress we are subjected to is not good for us. In fact, even with courses, tutorials and meetings that promise a magic formula for us, teachers, to adapt ourselves to everything, there is a basic principle: working with distance education was never part of my goal as a teacher! I never studied for that. I never wanted that. And my students deserve more than to stand in front of a computer or cell phone and wait for classes that I don't feel safe giving. Is it worth it?

\section{Excerpt 7:}

I don't feel ready for online teaching, I deal with the flaws with my internet connection and students every day, I'm working three times more and just getting more demands every day, but I'm doing my best for the love of the profession, to the teaching of languages and my students.

\section{Excerpt 8:}

I was not prepared for this. To work in a chair for 16 hours a day, with absurd demands and never ending the job. I don't live anymore. Small daily meetings are good for students to interact with other children, but the school does not think about anyone's mental health. Neither the students' nor the teachers'. They want the content to be fulfilled. Children do not have effective online learning in the same way that they would have offline, face-to-face. Online, content must be reinforced in several different ways. 
In order to deal with the pressure of reinventing their practices, we have observed that some teachers choose a safe ground and go back to (or continue) focusing on traditional classes, placing emphasis on content, in an attempt to demonstrate that they are doing something, they are performing their duties as instructors. However, this exclusive focus on content may be connected to a structural perspective of what language is and of what teaching and learning a language-in this case, involving children-represents. As presented in excerpt 8 , the teacher criticizes the school's approach, as it does not consider teachers or students, and puts content in the spotlight, not people. However, as defended by Freire (1987), reading the world precedes reading the word. Thus, teaching content without focusing on context, without taking students' realities and experiences into consideration, may result in a perceived lack of relevance. The next answer, excerpt 9, is also about the focus on content as a way to please the institutions and their clients:

\section{Excerpt 9:}

I have seen many texts, images and videos about the "love of teachers who reinvent education overnight because they love their students and do not want to see them harmed, without access to education". It annoys me so much. First, because we are not actually teaching. It's all make-believe. It is not class, it is an attitude of desperation to keep children connected to school. Secondly, these speeches ALWAYS say that students will not be harmed because "content" is being given. In other words, we are limiting "teaching", "class" "school", "education" to content only. This is disastrous for me! Even more in kindergarten and elementary education. Third because we are OBLIGATED! It's not love, no. If private school stops, it dies and we lose our job. Anyway, the teachers' efforts to conduct classes online are worthy. We were not prepared, everything has been improvised and we are exhausted. At my school, online classes are happening (except full-time English programs, which I teach) and we are also assembling kits with printed and cut activities, inks, string, books, etc., etc. All of these for the monthly fee to continue to be paid. That is the initial concern. And it makes sense. I don't want to lose my job. And because we do not want to lose our jobs, we are reducing teaching to content, pretending that everything is normal at school, talking about distance learning as all this was not hopeless. 
The feelings expressed by this participant seem to reinforce what some researchers have been stating: TEYL is not just a love for children and good intentions (KAWACHI-FURLAN; ROSA, 2020); it requires much more than that. The teacher in excerpt 9 expresses such a feeling by firmly saying that the way classes are being conducted is "make-believe". At the same time, it is possible to identify in her/his words an outrage facing an obligation to continue doing things in any way possible not to lose jobs. In order to (try to) guarantee her/his position at the school, the way out seems to be to reduce teaching to content, acting as if everything is just as it has always been at school.

Ferreira and Takaki (2014) remind us that the conventional and structural models of teaching English and other languages through isolated words and sentences, following a linear sequence from what is considered easy to what is more difficult, is not compatible with our society. The authors remark that learners need to have opportunities to work with new ways of making meaning and of constructing multimodal knowledge. In this sense, it is imperative for language, seen as a homogenous and structural concept, to be revisited to attend new forms of communication and negotiation of meanings.

Based on participants' testimonials, it can be observed that the pandemic times have definitely reinforced traditional practices in TEYL. Despite the achievements in this area regarding the importance of considering children's complete development, not only linguistically speaking, a desperate need to focus on language structure seems to be at the center of attention. However, as suggested by García (2020), we should be unlearning and relearning with the current situation in order to act differently and review this focus on language as something that can be measured. Monte Mór (2009) also asserts the need to discuss what we expect from education. Although the author is not referring to the COVID-19 pandemic, her quote fits the actual scenario, as this idea of reproduction is frequently seen. As she states,

[w] hat seems to be at stake is the need to define a new process of education. The current moment reveals a binary dispute between reproduction - which enables control, measuring, the identification of who learns more, or less, in the teachinglearning process - and creation, creativity and critique. (MONTE MÓR, 2009, p. 184). 
Several authors (DUBOC, 2020; FERRAZ, 2020; LIBERALI, 2020) have pointed to the need to reflect on our goals as educators, especially in times like these, in which social differences and injustices have become more explicit. Thus, seeking to problematize the consequences of what Sousa Santos (2020) calls "The cruel pedagogy of the virus", it is fundamental to consider the possibilities of language education, envisioning education as a possibility to value life (LIBERALI, 2020), which is the focus of the next section.

\section{$4 \operatorname{Re}($ thinking) critical literacies in TEYL}

The analysis of participants' answers allowed us to reflect on the reasons why we defend language education with children. Besides to the well-known benefits of knowing additional languages, we are interested in the possibility of educating through language in the process of developing linguistic awareness (TONELLI; CORDEIRO, 2014; MENEZES DE SOUZA, 2019), focusing on the appreciation of differences and the transformation of people and their realities, seeking social justice, as suggested by Rocha (2018).

From this perspective, we tend to distance ourselves from conservative ideas of language that emphasize the role of native speakers and limit language to a system of rules and sounds. We are inclined to follow García's (2020) proposal of language as a verb, that is, languaging, as something that cannot be measured, since language is related to social practice. In this dialogic view, the encounters enabled through language are rich moments of constructing meaning and of questioning dominant ideologies. This collaborative process of "meaning making" resonates with the premises of critical literacy, which is a "political orientation to teaching and learning" (LUKE, 2014, p. 21-22), focusing on "critique and transformation of dominant ideologies, cultures and economies, institutions, and political systems" (p. 21-22).

According to Duboc and Ferraz (2011), critical literacy stems from the contributions of critical education, which was influenced by Paulo Freire's pedagogy. Freire proposes a focus on the problematization of social issues and a different attitude when dealing with texts, aiming at understanding privileges. As suggested by Valério and Mattos (2018), there is an emphasis on "citizenship education over curriculum content" (p. 332). 
Thus, critical literacy is not a method. It "challenges the educational status quo rephrasing and resignifying the 'original' concept of literacy and the entire homogeneity and rigidity that this concept entails regarding the process of meaning making" (DUBOC; FERRAZ, 2011, p. 22). Lankshear and Knobel (2007) stress the idea that literacies are social practices, wherein reading and writing are conceived from a sociocultural perspective involving different spheres of society (expanding the idea that texts are only able to be read and written). In this context, the intangible idea of language and culture starts to be questioned as they are part of social relations, not fixed structures. Along these lines, Monte Mór (2014) calls attention to the need to focus on social engagement, agency and active participation in order to live in contemporary societies.

In the following excerpt, one of the participants mentions that the COVID-19 pandemic exposed the injustices of society. As a teacher, it is painful to observe that some children are able to continue to have their English lessons, while others do not even have a computer at home:

\section{Excerpt 10:}

(...) For me, the most painful thing is to see how unfair and excluding our society is. While private schools are maintaining the frequency and the quality of classes even at a distance, the public sector is struggling to involve students in these new practices and provide "some" contact with the schools for those who do not have access to the internet, who do not have a computer, cell phone or television. A sad reality revealed by this pandemic.

Duboc (2020) laments the current situation as all children have been experiencing the effects of school deprivation. On the one side, privileged children are under the effects of remote online teaching, which tries to control children through neobehaviorism without considering the developments in the educational field (DUBOC, 2020). On the other side, poor children are left vulnerable, in potential situations of domestic violence, child labor and hunger, without the possibility of participating in educational proposals.

\footnotetext{
${ }^{6}$ In the original: "Tal orientação, portanto, desafia o status quo educacional refraseando e ressignificando o conceito "original" de alfabetização e toda a homogeneidade e fixidez que este conceito encerra no que se refere ao processo de significação".
} 
In the face of this scenario, as educators, we are disheartened at the feeling of being powerless. We advocate that a child's right to education must be guaranteed and that those who have access to online classes should have their needs and wants considered. Thus, advocating for critical literacy seems to be in accordance with the possibility of questioning what is imposed upon, and by, our society. Robinson and Diaz (2005) argue that the role of early childhood educators is to make a difference in children's lives:

This is possible not only on the broader level of advocating for their rights, but also challenging and disrupting normalizing discourses through the curriculum that we teach, the policies that inform our practice and the pedagogies that we utilize in teaching children. (ROBINSON; DIAZ, 2005, p. 7).

In this sense, we find comfort when one teacher (excerpt 11) emphasizes the importance of considering children as the center of the process, aiming for proposals that are suitable for and meaningful to students.

\section{Excerpt 11:}

(...) I received training before starting remote education, but everything that is planned is just a possibility. We face several variables, one of which is the quality of the internet connection in each home, parents with their children translating what is being said ... There are many details, but with respect to children and quality education that I have always proposed to deliver I surrender to the demand and try to carry out / to teach relevant education, which makes sense for each child's developmental phase. (I teach classes for children from 1 to 6 years old).

Lopez-Gopar (2019) considers that teachers reinvent critical pedagogies on a daily basis by proposing changes that cater to their students and consider the local context:

Grounding their teaching 'praxis' or otherwise 'reflection plus action' (Freire 1970) in the local contexts and physical realities of their students, many teachers resist the effects of the ELT industry and negotiate their and their students' identities within the search for social justice [...] (p. 234). 
English teachers who work with early childhood education are constantly reinventing their practices, as the field as a whole is commonly described as experimental by many of these teachers. Although this teaching area is not new in our country and many private and public schools offer the English language since kindergarten, there is still discussion on who would be legally allowed to teach English for children. As stated by Rinaldi (2011), there are no documents prohibiting those who graduate from Language courses to work in TEYL. However, the restructure of Language courses is undeniable and urgent ${ }^{7}$ in order to follow the changes and demands of the contemporary society. As a consequence of such scenario, most teachers who begin in this area mention they were not prepared for this (TONELLI; CRISTOVÃO, 2010; TUTIDA, 2016; LEMES, 2017; CIRINO; DENARDI, 2019; LIMA, 2019). Currently, during the pandemic, this need to change their lessons and renew some ideas and proposals has become imperative. However, what has been observed is a redesign only in the sense of how classes are being delivered, that is, through the use of technological devices. The core of lessons, though, lies on content that can be measured and not on what is significant to children in terms of their overall development (not just linguistically speaking).

We agree with Lopez-Gopar (2019), on how focusing on our local contexts is a way of resisting the English Language Teaching (ELT) industry, as it is possible to actually consider children's needs, and not be restricted to following "successful" methodologies or global textbooks. Nonetheless, when the focus of online classes during the pandemic is on the structure of language, the idea of resistance seems inappropriate. Liberali (2020) asserts that it is time to break alienating patterns of teaching and learning, seeking to construct critical minds in students through actions that are not limited to reproducing what is known as the standard pattern. In this sense, it is crucial to listen to what children want, as well as teachers' demands and reflections, in an attempt to depart from dominant and hegemonic patterns. Boveda and Bhattacharya (2019, p. 21) alert that "it is not that the subaltern is not

\footnotetext{
${ }^{7}$ It is also important to highlight that a group of English teacher educators, focused on the need of restructuring Language courses, is carrying out a manifesto demanding this urgent reformulation. More information is available at: https://sites.google.com/view/ manifesto-consulta-pblica?fbclid=IwAR2XDEJ2dC6T5-qfk5IeVIcrRhqb2JyRlfpqsmW Djy22cADBHcr0ZmD-BvQ
} 
speaking, but how she is being listened to and who is listening to her that informs the paths of possibilities", which seems to converge with the idea presented by one of the teachers, as follows:

\section{Excerpt 12:}

(...) Let us think about children, there are some who do not even have a computer. How can we think about learning with so much inequality? How can we think about content, if what many need is to be at school to eat? Teachers are being transformed into "youtubers" as if it was the most interesting thing in the world. And for those who need it: planning lessons, recording lessons, editing videos, sending activities, correcting them later, meeting their own needs and those of their families, I wonder where they find some space for themselves. There is learning in all of that too. It is undeniable, but the demand is being relentless. I hope for better days.

As suggested by the participant in excerpt 12, the current scenario is marked by questions (such as "How can we think ...?") and uncertainties. Instead of allowing ourselves to wonder about and seek for alternatives collaboratively, many institutions are dictating what must be done, following the capitalist logic of education as a commodity, and as it is part of the market, it cannot stop. The criticism here begins with the pressure either to have online classes no matter what happens or to return to face-toface classes without even minimal care and subsidies. The point is that there are few initiatives from the State and the organs that are responsible for nationwide child education to collectively decide alternate paths that could promote more than just teaching content far from learners' realities. Carvalho (2020) stresses that schools are not physical in this pandemic context; they are in social media, online platforms and other digital resources and, therefore, they should be centered on the collectives.

In excerpt 13, one of the participants mentions teachers' limitations because of online methods:

\section{Excerpt 13:}

(...) When following the work of other educators and educational networks, I saw that the content covered was mainly based on the lexical repetition. In a holistic perspective, the child learns through movement, interaction, touch, eye to eye contact, from experiences in which they can get their hands dirty. And all these elements which are necessary for the child's development are limited by the distance learning modality. 
Online classes certainly limit the possibilities of engaging children in activities that embrace their needs, especially younger children. The advantages and benefits of face-to-face classes are out of the realm of possibility, but despite the difficulties of virtual lessons, this modality cannot be solely blamed for an exclusive focus on content and, in the case of TEYL, an exclusive focus on vocabulary. What seems to be at stake are teachers' concepts of language and the constraints between teachers' perspectives and schools' demands (which, in turn, follow parents' requests and/or a global syllabus from an international program). Thus, if language is seen as social practice and teachers are involved in a pedagogy that emphasizes active citizenship such as multiliteracies, learners are at the center of the process, acting as agents of knowledge production (COPE; KALANTZIS, 2009). Mattos (2014) states that working with critical literacy targeted at participatory citizenship fosters critical thinking and global awareness that contribute to students' lives outside the school walls.

Considering critical literacy as a prospect during pandemic times (and after) is what gives hope to resist this return to structural teaching and to fight for pedagogical and curricular possibilities that correspond to the changes in society (MONTE MÓR, 2009) in an attempt to overcome imposed standard patterns and the influence of the ELT industry, as discussed by Lopez-Gopar (2019). Insisting on critical literacy and critical language education with children is a constructive possibility, as we are committed to problematize what has been described as "normal" and patterns that have been naturalized as "correct". The following quote represents our intentions as educators in this area:

Engaging children in critical thinking and reflection on the normalizing discourses that operate in terms of identities, difference, power relations and inequality can enable racist, sexist, homophobic and classist discourses, among others, to be disrupted and challenged, opening up new and more equitable ways of looking at the world (ROBINSON; DIAZ, 2005, p. 42).

In summary, critical language education represents an opportunity to break the cycles of repeating pre-established teaching models and methodologies for teachers. To learners, it means a possibility to expand one's views and deconstruct the interpretative habitus (MONTE MÓR, 
2019), hoping that children may become authors of their own discourses, not only reproducing them, as suggested by Malta (2019). In the next section, we discuss the role of teacher education in this context.

\section{Teacher education: re-educating to expand our perspectives}

We begin this section with Biesta's proposal (2020, p. 30) for reflecting on the question "What is this asking from us?". The author argues that the current moment requires a response to this, not just an automatic reflex, calling upon the university not to look for the obvious, but to help "each other to look elsewhere". In this sense, as teachers, teacher educators and researchers committed to language education with children, we seek alternatives to reflect on what the current moment asks from us, especially regarding the education of early childhood English teachers.

Morgan (2019) argues that the way teacher educators organize their programs and curricula reflects the dimensions of critical work, for instance when these programs are open to possibilities and not locked into what is considered right or true. The author favors reflexive and transformative actions that foster critical awareness, interconnecting theory and practice. To him, this is an essential educational goal, mainly in unequal societies, as this "speaks to the negotiation of identity and the development of values/morals that shape our understanding of democratic life and social responsibility" (MORGAN, 2019, p. 270).

Ferraz (2018) questions the term "teacher education" as it reveals a hierarchical proposition since the teacher educator is responsible to educate and mold the future teacher. To the researcher, the praxis of teacher educators cannot be restricted to methodologies and textbooks, emphasizing the vertical relationship between teachers and students. The author defends critical teacher education that goes beyond the institutionalized undergraduate course in Languages and Literature, encouraging other formats of teacher education programs that complement and challenge the current traditional models.

In accordance with what is proposed by Ferraz (2018), when considering teacher education and TEYL, it is fundamental to expand our views on the possibilities of teacher education. The area of TEYL is wellknown for its issues related to initial teacher education. Tonelli, Ferreira and Belo-Cordeiro (2017) contend that, although English teaching for children 
is a reality in Brazil, teacher education does not occur on a regular basis in many higher education institutions. Therefore, teachers often seek for opportunities to obtain qualifications in this area through courses, events, webinars, research groups, participation in social media groups related to this topic, and others. The following answer addresses the need to reflect on teacher education and to consider flexibility in this process:

\section{Excerpt 14:}

We, teachers of English to children, are going through a process of reinvention. First, I believe that remote or on-line classes are better than nothing, after all, somehow, we are managing to continue with the learning of our students. However, this pandemic situation exposes the already precarious education of our teachers. We are, almost entirely, professionals with no initial or continuing education to work in our segment and this, in itself, is already challenging. Now, more than ever, we need to pay attention to the urgency and importance of turning our attention to the training of future English teachers to children. Did we miss the classroom interaction that is so important for learning a language? Yes. Do we know how long this will last? No. But what we can learn from this situation is that teacher education will need to be one step ahead for the future. As in any job where strong, adaptable foundations are needed, ours will also need to be. Consistent, flexible and very, very, sensitive.

As pointed out by the participant, the pandemic has exposed the difficulties of teacher education, especially in relation to TEYL. We agree with the participant that the moment requires proposals that are consistent, flexible and sensible. In this sense, it seems fitting to focus on teacher education associated with critical education, appreciating educators' subjectivities, identities, and histories in this web of knowledge, as stated by Duboc and Ferraz (2020). Thus, expanding the concept of teacher education implies understanding that it is a broad process, one which is not restricted to a single, specific undergraduate course, although Languages and Literature courses should minimally guarantee that future teachers have contact with the area of TEYL during their teaching license program. Monte Mór (2018) asserts that this expansion in teacher education demands more from teachers and highlights the need to recognize teachers' careers with specific plans to value this profession.

According to Lima and Neto (2019), it is not possible to affirm that there is no teacher education for English teachers to children. There are 
no regulations and official policies that institutionalize this practice, but there are indeed initiatives in some institutions (usually related to individual efforts) and teacher engagement in their own development, which was described as learner-teacher-autonomous by Malta (2019). As mentioned by the majority of the participants of this research, no one was prepared for the current scenario. Teachers are being educated as they are learning about online classes, digital resources and the effects of the COVID-19 pandemic. In excerpt 15, the participant emphasizes that teachers face challenges in face-to-face classes as well, mainly due to the pressure of children's families:

\section{Excerpt 15:}

We are facing a scenario that none of us was prepared for. Nobody until today had to change the way of teaching overnight. The beginning was very difficult, but after the adaptation period, I believe that we have made progress. The scenario is still not the ideal one, since even in times of faceto-face classroom teaching English curriculum is not seen as essential. Therefore, I believe that teaching English remotely will have more losses than other curricular subjects, since with the excess of information, and sometimes activities, that families are receiving, if they have to prioritize some discipline, it will not be English. We face difficulties with face-to-face teaching in this regard and in addition, some families feel they can determine what and how teachers will do their job. There was not enough time for relevant training. Everything that was and is being done had to be carried out during the process. Training is still going on as we discover new tools and ways to make the work happen with quality.

As evidenced, the participant points out that English classes are not considered essential in both modes, but online teaching may present more disadvantages, as families might prioritize other disciplines over English. Many participants defended that parent involvement in online classes is fundamental to the development of lessons and to have satisfactory results regarding child engagement. In this sense, current times demand that teacher education focuses on the local context, which involves children, their families, teachers, schools and institutions (represented in face-to-face or virtual interactions), as well as their subjectivities and backgrounds.

Therefore, this moment is asking from us more than just reflexes (BIESTA, 2020). We are called to reflect on the aims of language teaching, on what is expected from language education with children, and on how 
teacher education programs can become more sensitive to the current scenario and its consequences. It is solely through reeducating ourselves about what has been traditionally associated with TEYL that we can find alternative paths. We need to begin, as defended by Biesta (2020), by revisiting the idea of teaching:

This is not about teaching as a form of control - the travesty of education that has given teaching such as bad name (see Biesta, 2017) - but about teaching as an act of (re)presenting the world and inviting and encouraging students to pay attention, individually and collectively, to what is 'out there'. This is the school, not as a place for learning or a learning community, online or otherwise, but as a place where you are giving what you were not looking for, first of all because you may not even be aware that you could be looking for it (BIESTA, 2020, p. 31).

The author invites us to consider the schools as possibilities to expand our views. This proposal is urgent, as we are all being changed by these pandemic times; at the least, we should be open to changes that focus on more thoughtful and humane relations. On this subject, Lopez-Gopar (2019) stresses the relationship between critical pedagogies and social justice, explaining that the first may not change the world, but can enable small changes and opportunities. In the author's words, [these] "can make a student feel intelligent, creative and truly appreciated at that particular moment. The student, then, can hopefully go on to change the world" (p. 241). And a real change is what we really need, mainly when it comes to TEYL, which is a matter of being fair with those who are marginalized either for not having the opportunity to learn a language or for being exposed to conflictual teaching and learning processes that seem to give a false impression that everything is under control.

\section{Final reflections}

Early in the beginning of the pandemic some concerns came to our minds: What about TEYL? Would there be classes? What about the teachers? The children? How can we deal with the various issues involved with the many possibilities of the COVID-19 scenario? With these questions in mind, we felt the need to discuss teachers' perspectives on the impacts 
of the COVID-19 pandemic on TEYL. In order to reach this goal, we generated data through an online questionnaire containing 10 questions, which allowed us to know the background and current teaching situation of a group of 62 English teachers.

For the purpose of this study, we focused on question number 9 , which invited teachers to share their thoughts, experiences and concerns about TEYL in pandemic times, as if they were posting their reflections in social media platforms. Analyzing participants' answers, it was evident that the majority of teachers were exhausted from dealing with this unusual situation while trying to cope with the demands placed upon them by schools (and parents). Moreover, some of them described an exclusive focus on content in an attempt to show that teachers were doing something (they were acting). This situation was understood as a return to traditional practices in order to give an impression of control (again attending requests by schools and parents).

As discussed by several researchers, the area of TEYL has had many achievements that involve considering the child's complete development (such as physical, cognitive, social, linguistic, affective, among other areas). However, it seems that the pandemic has been challenging these accomplishments, as observed in participants' answers. It is not only a focus on content that is being discussed here, but also the effort to guarantee a child's right to language education, as well as the need to consider the child and their context at the center of this process. We agree with Quinteiro (2019), who expressed that education is about attending to the child's individual needs, as it is related to the possibility of considering their legacy as human beings.

Thus, as proposed by Biesta (2020), the current moment requires reflections, not just immediate actions. It is fundamental to problematize our views on what language means, as well as our idea of what learning and teaching an additional language is, especially with children. Pursuing critical language education with children implies revisiting what has commonly been associated with this area, resisting the influence of the ELT industry (LOPEZ-GOPAR, 2019) and neoliberalism that tend to naturalize social exclusion and hegemonic perspectives of language and teaching. It requires rethinking our understanding of children and childhood.

Robinson and Diaz (2005) argue that for many child educators, critical education is unsuitable for and irrelevant to children. Nonetheless, according 
to the authors, this is a result of dominant discourses of childhood, which have perpetuated "white, Western and middle-class values that have historically been linked to strong religious and moral discourses" (p. 6), contributing to romanticizing childhood and describing it as a period of innocence.

Defending critical language education with children implicates placing emphasis on children's subjectivity, individuality and history, as well as on their complete development. It means creating possibilities for children to question and expand their views (MONTE MÓR, 2019) on what has been traditionally imposed by society. In this sense, we argue that reframing teacher education is necessary so that TEYL is part of teacher education programs and the concept of teacher education can be expanded to include all teachers' efforts in this search to have specific qualifications to work with children. In this sense, we agree with Quinteiro's (2019) problematization of whether teacher education programs are creating possibilities for teachers to respect children in their individuality as well as in their human grandiosity. In accordance with Yi and Jang (2020), despite all the issues discussed here, we believe a word of hope is necessary. Although the effects of the COVID-19 pandemic and remote teaching and learning are still uncertain, the authors invite us to consider new, collaborative possibilities for teaching and learning. As educators, we keep seeking for opportunities to value what is essential in education: human relations. We conclude this paper with a participant's reflection on this matter:

Suddenly, noise was transformed into silence, faces were changed by a screen, self-confidence by insecurity, the dirty hands from markers are now clean, busy with buttons and the mouse. How can we convert hours of planning in cold classes, limited to the written word and to the computer screen; without children's coloring, without contemplating the "peacher" pronunciation of recently lost teeth. How to convince everyone of our difficulty in transforming classes of pronunciation, writing, listening and speaking into a blank sheet of paper, tiny, so that it fits the screen of a smartphone. Someone, please, teach me how to translate all the techniques, researched and applied for years, into something virtual, show me how to turn ludic words fixed to one activity, without human intervention and that they can become real, useful, and connected to our reality. Teach me how to use an app through which I can access the feelings, in face of a new vocabulary 
or a new song, that our children express! Teach me how to conform to this new reality, to believe that, somehow, our students have not lost interest in learning a second language. I am not a pessimist. I am just each day more convinced that teaching is something surprisingly human, which even the best search engines, apps of messages, sound and image software, have still not managed to transcend the pedagogical techniques based on the simplest humane skills.

\section{Authors' contribution}

Both authors participated in each phase of the study. They designed the questionnaire and contacted the participants. The data was qualitatively analyzed by both authors. Sections 1, 3, 5, and 6 were written collaboratively by the two authors. Claudia Kawachi-Furlan authored section 4 and Juliana Tonelli authored section 2 individually.

\section{References}

ÁVILA; P. TONELLI, J. R. A. A ausência de políticas para o ensino de língua estrangeira no Ensino Fundamental I: reflexões acerca da obrigatoriedade da oferta nos currículos das escolas municipais públicas. Revista X, Curitiba, v. 13, n. 2, p. 111122, 2018. DOI: https://doi.org/10.5380/rvx.v13i2.55588. Available at: https:// revistas.ufpr.br/revistax/article/view/55588/36090. Retrieved on: Aug. 24, 2020. BIESTA, G. Back to school! A Future for the University Post-Covid-19. Journal of Educational Philosophy and Theory, [S.A, Reimagining the New Pedagogical Possibilities for Universities Post-Covid-19, p. 30-31, 2020. Doi: https://doi.org/10.1080/00 131857.2020.1777655. Available at: https://www.tandfonline.com/doi/full/10.1 080/00131857.2020.1777655. Retrieved on: Jul. 05, 2020.

BOVEDA, M.; BHATTACHARYA, K. Love as De/Colonial Onto-Epistemology: A Post-Oppositional Approach to Contextualized Research Ethics. The Urban Review, [S.I], v. 51, p. 5-25, 2019. DOI: https://doi.org/10.1007/s11256-01800493-z. Available at: https://link.springer.com/article/10.1007/s11256-01800493-z. Retrieved on: Jul. 5, 2020.

CARVALHO, M. P. Reflexões finais: performar a vida para enfrentá-la de forma consciente. In: LIBERALI, F. C.; FUGA, V. P.; DIEGUES, U. C. C; CARVALHO, M. P. (ed.). Educação em tempos de pandemia: brincando com um mundo possível. Campinas, SP: Pontes Editores, 2020. p. 387-390. 
CARVAlHO, I.; TONELLI, J. R. A. The Younger, the Harder: The Challenges of Teaching English to Very Young Learners. REVELLI - Revista de Educação, Linguagem e Literatura, Goiás, Inhumas/GO, v. 8, n. 2, p. 1-18, jun. 2016. Available at: https:// www.revista.ueg.br/index.php/revelli/article/view/4490. Retrieved on: Aug. 24, 2020 .

CHAGURI, J. de P.; TONELLI, J. R. A. Existe uma política de ensino-aprendizagem de língua estrangeira para crianças? In: TONELLI, J. R. A.; CHAGURI, J. de P. (ed.). Ensino de língua estrangeira para crianças: o ensino e a formação em foco. Curitiba: Appris, 2012. p. 37-57.

CIRINO, D; DENARDI, A. C. Há espaço para o ensino de Inglês para crianças no currículo de cursos de Letras Português- Inglês? Sêmina: Ciências Sociais e Humanas, Londrina, v. 40, n. 2, p. 209-224, jul./dez., 2019. DOI: 10.5433/1679-0383.2019v4 0n2p209. Available at: http://pepsic.bvsalud.org/pdf/sem/v40n2/a06.pdf. Retrieved on: Jun. 24, 2020.

COPE, B.; KALANTZIS, M. "Multiliteracies": New Literacies, New Learning, Pedagogies. Pedagogies: An International Journal, [S.l.], v. 4, n. 3, p. 164-195, 2009. DOI: https://doi.org/10.1080/15544800903076044

DUBOC, A. P. M. Do tecido da vida, do puído do vírus: sobre crianças, novelos e linhas. Revista X, Curitiba, v. 15, n. 4, p. 126-131, 2020. DOI: http://dx.doi. org/10.5380/rvx.v15i4.76346. Available at: https://revistas.ufpr.br/revistax/ article/view/76346. Retrieved on: Oct. 15, 2020.

DUBOC, A. P. M.; FERRAZ, D. M. Letramentos críticos e formação de professores de inglês: currículos e perspectivas em expansão. Revista X, Curitiba, v. 1, p. 19-32, 2011. DOI: http://dx.doi.org/10.5380/rvx.v1i1.2011.23056. Available at: https:// revistas.ufpr.br/revistax/article/view/23056. Retrieved on: Oct. 15, 2020.

DUBOC, A. P. M; FERRAZ, D. M. What's Behind a Literacy War? A Discursive and Political Analysis of the Neoconservative Brazilian Literacy Policy. Journal of Multicultural Discourses, [S.l.], v. 15, n. 4, p. 1-23, 2020. DOI: https://doi.org/10.10 80/17447143.2020.1800714

FERRAZ, D. M. Educação linguística e transdisciplinaridade. In: PESSOA, R. R.; SILVESTRE, V. P. V.; MONTE MÓR, W. (ed.). Perspectivas críticas de educação linguística no Brasil: trajetórias e práticas de professoras(es) universitárias(os) de Inglês. 1. ed. São Paulo: Pá de Palavra, 2018. p. 105-119.

FERRAZ, D. M. O mecanismo, o câncer e o (triste) Brasil de 2020. Revista PUB: Diálogos Interdisciplinares, [S.l.], 2020. Available at: https://www.revista-pub.org/ post/16082020. Accessed on: 26 Aug. 2020. 
FERRAZ, D. M.; NASCIMENTO, A. K. O. Language Education and Digital/ New/Multi-Literacies: Do We Teachers Consider what Happens Outside the School Walls? In: AMORIM, S. S.; SANTOS, V. M. (ed.). Sujeitos e práticas educativas: experiências, saberes e perspectivas. Aracaju, SE: EDUNIT, 2019. p. 43-65.

FERREIRA, G; TAKAKI, N. H. Epistemologias de novos e múltiplos letramentos, identidade pós-moderna: repensando perspectivas para o ensino e aprendizagem de línguas. Revista Primeira Escrita, Aquidauana, n. 1, p. 119-133, nov. 2014. Available at: https://periodicos.ufms.br/index.php/revpres/article/view/197. Retrieved on: July 26, 2020.

FREIRE, P. Pedagogia do oprimido. 11. ed. São Paulo: Paz e Terra, 1987.

GARCÍA, O. The Education of Latinx Bilingual Children in Times of Isolation: Unlearning and Relearning. MinneTESOL Journal, v. 36, n. 1, [s.p.], 2020. DOI: https://doi.org/10.1080/09500782.2020.1825476. Availbale at: http:// minnetesoljournal.org/current-issue/invited-article/the-education-of-latinxbilingual-children-in-times-of-isolation-unlearning-and-relearning . Retrieved on: July 26, 2020.

JORDÃO, C. M. Uma jornada crítica em retrospecto, ou de como se respira no mar. In: PESSOA, R. R.; SILVESTRE, V. P. V.; MONTE MÓR, W. Perspectivas críticas de educação linguística no Brasil: trajetórias e práticas de professoras(es) universitárias(os) de Inglês. 1. ed. São Paulo: Pá de Palavra, 2018. p. 71-82.

KAWACHI-FURLAN, C. J.; ROSA, M. M. Mitologia do ensino-aprendizagem de inglês para crianças. Revista Estudos em Letras, Cassilândia, v. 1, n. 1, p. 21-34, jul./dez., 2020. Available at: https://periodicosonline.uems.br/index.php/ estudosletras/article/view/519._Retrieved on: July 2, 2020.

KUBOTA, R. The Multi/Plural Turn, Postcolonial Theory, and Neoliberal Multiculturalism: Complicities and Implications for Applied Linguistics. Applied Linguistics, Oxford, v. 37, n.4, p. 474-494, 2016. DOI: https://doi.org/10.1093/ applin/amu045. Available at https://academic.oup.com/applij/articleabstract/37/4/474/1741757. Retrieved on: July 16, 2020.

LANKSHEAR, C.; KNOBEL, M. Sampling "the New" in New Literacies. In: LANKSHEAR, C.; KNOBEL, M. (ed.). A New Literacies Sampler. New York: Peter Lang Publishing, 2007. p. 1-24.

LEMES, F. M. M. Formação crítica docente e seu reflexo no ensino crítico de inglês para crianças: experiências transformadoras. In: TONELLI, J. R. A.; PÁDUA, L. de S.; OLIVEIRA, T. R. R (ed.). Ensino e formação de professores de línguas estrangeiras para crianças no Brasil. Curitiba, PR: Appris, 2017. p. 151-175. 
LIBERALI, F. C. Construir o inédito viável em meio a crise do coronavírus lições que aprendemos, vivemos e propomos. In: LIBERALI, F. C.; FUGA, V. P.; DIEGUES, U. C. C; CARVALHO, M. P. (ed.). Educação em tempos de pandemia: brincando com um mundo possível. Campinas, SP: Pontes Editores, 2020. p. 13-21.

LIMA, A.P. Desenvolvimento profissional de professores de inglês para crianças do Ensino Fundamental I: possibilidades para a formação e trabalho docente. 2019. $299 \mathrm{f}$. Dissertation (Ph.D. in Education) - Universidade Estadual Paulista, UNESP, Rio Claro, 2019.

LIMA, A. P.; NETO, S. S. A formação em serviço e o desenvolvimento profissional de professores de inglês para crianças. PERcursos Linguísticos, Dossiê: Ensinoaprendizagem de línguas estrangeiras com crianças, Vitória, v. 9, n. 23, p. 130-147, 2019. Available at: https://periodicos.ufes.br/percursos/article/view/27929. Retrieved on: May 15, 2020.

LÓPEZ-GOPAR, M. E. Critical Pedagogy and Teaching English to Children. In: GARTON, S.; COPLAND, F. (ed.). The Routledge Handbook of Teaching English to Young Learners. New York, NY: Routledge, 2019. p. 234-246. DOI: https://doi. org/10.4324/9781315623672-16

LÜDKE, M.; ANDRÉ, M. E. D. A. Pesquisa em Educação: abordagens qualitativas. 2. ed. Rio de Janeiro: E.P.U., 2017. p. 112.

LUKE, A. Defining Critical Literacy. In: PANDYA, J. Z.; AVILA, J. (ed.). Moving Critical Literacies Forward: A New Look at Praxis Across Contexts. New York: Routledge, 2014. p. 19-31.

MALTA, L.S. Além do que se vê: educação crítica e letramentos, formação de professores e prática docente no ensino de inglês para crianças de 2 a 5 anos. 2019. 128f. Dissertação (Mestrado em Linguística) - Universidade Federal do Espírito Santo, Vitória, 2019.

MATTOS, A. M. A. Construindo cidadania nas aulas de inglês: uma proposta para o letramento crítico. In: TAKAKI, N. H; MACIEL, R. F. Letramentos em terra de Paulo Freire. Campinas, SP: Pontes Editores, 2014. p. 171-191.

MENEZES DE SOUZA, L. M. T. Educação linguística: repensando os conceitos de língua e linguagem. In: FERRAZ, D. M.; KAWACHI-FURLAN, C. J. (ed.). Bate-papo com educadores linguísticos: letramentos, formação docente e criticidade. São Paulo: Pimenta Cultural, 2019. p. 245-258. DOI: https://doi.org/10.31560/ pimentacultural/2019.249.244-258

MILLER, I. et al. Teaching English to Young Learners: Some Reflective Voices from Latin America. In: GARTON, S.; COPLAND, F. (ed.). The Routledge Handbook 
of Teaching English to Young Learners. New York, NY: Routledge, 2019. p. 508-522. DOI: https://doi.org/10.4324/9781315623672-32

MONTE MÓR, W. Foreign Languages Teaching, Education and the New Literacies Studies: Expanding Views. In: GONÇALVES, G. R. et al. (org.). New Challenges in Language and Literature. Belo Horizonte: FALE/UFMG, 2009. p. 177-189.

MONTE MÓR, W. Convergência e diversidade no ensino de línguas: expandindo visões sobre a "diferença". Polifonia, Cuiabá, MT, v. 21, n. 29, p. 234-253, jan-jul., 2014. Available at: https://periodicoscientificos.ufmt.br/ojs/index.php/polifonia/ article/view/1940. Retrieved on: Aug. 17, 2020.

MONTE MÓR, W. Sobre rupturas e expansão na visão de mundo: seguindo as pegadas e os rastros da formação crítica. In: PESSOA, R. R.; SILVESTRE, V. P. V.; MONTE MÓR, W. (ed.). Perspectivas críticas de educação linguística no Brasil: trajetórias e práticas de professoras(es) universitárias(os) de Inglês. 1. ed. São Paulo: Pá de Palavra, 2018. p. 265-278.

MONTE MÓR, W. Letramentos críticos e expansão de perspectivas: diálogo sobre práticas. In: JORDÃO, C. M.; MARTINEZ, J. Z.; MONTE MÓR, W. (ed.). Letramentos em prática na formação inicial de professores de inglês. 2. ed. Campinas, SP: Pontes Editores, 2019. p. 315-335.

MORGAN, B. Critical Literacies in Language Teacher Education: Constraints and Opportunities. In: FERRAZ, D. M.; KAWACHI-FURLAN, C. J. (ed.). Batepapo com educadores linguisticos: letramentos, formação docente e criticidade. São Paulo: Pimenta Cultural, 2019. p. 269-283. DOI: https://doi.org/10.31560/ pimentacultural/2019.249.224-239

MOURÃO, S. Research into the Teaching of English as a Foreign Language in early Childhood Education and Care. In: GARTON, S.; COPLAND, F. (ed.). The Routledge Handbook of Teaching English to Young Learners. New York, NY: Routledge, 2019. p. 425-440. DOI: https://doi.org/10.4324/9781315623672-27

PINTER, A. Research Issues with Young Learners. In: GARTON, S.; COPLAND, F. (ed.). The Routledge Handbook of Teaching English to Young Learners. New York, NY: Routledge, 2019. p. 411-424. DOI: https://doi.org/10.4324/9781315623672-26 QUINTEIRO, J. Educação, infância e escola: a civilização da criança. Perspectiva, Florianópolis, v. 37, n. 3 p. 728-747, jul.-set., 2019. DOI: https://doi. org/10.5007/2175-795X.2019.e54108 . Available at: https://periodicos.ufsc.br/ index.php/perspectiva/ article/view/2175-795X.2019.e54108. Retrieved on: May $15,2020$. 
RINALDI, S. O futuro é agora: possíveis caminhos para a formação de professores de espanhol como língua estrangeira para crianças. 2011. 260f. Tese (Doutorado em Educação) - Faculdade de Educação da Universidade de São Paulo, Universidade de São Paulo, São Paulo, 2011.

ROBINSON, K. H.; DIAZ, C. Diversity and Difference in Early Childhood Education: Issues for Theory and Practice. Berkshire, England: Open University Press, 2005.

ROCHA, C. H. Provisões para ensinar LE no Ensino Fundamental de $1^{a}$ a $4^{a}$ séries: dos Parâmetros Oficiais e Objetivos dos Agentes. 2006. 340f. Dissertação (Mestrado em Estudos da Linguagem) - Instituto de Estudos da Linguagem, Universidade Estadual de Campinas, Campinas/SP, 2006.

ROCHA, C. H. Memórias e histórias de uma professora de inglês: por entre reflexões e vivências do letramento crítico. In: PESSOA, R. R.; SILVESTRE, V. P. V.; MONTE MÓR, W. (ed.). Perspectivas críticas de educaşão linguística no Brasil: trajetórias e práticas de professoras/es universitárias/os de inglês. São Paulo: Pá de Palavra, 2018, p. 83-94.

SOUSA SANTOS, B. A cruelpedagogia do vírus. Coimbra: Edições Almedina, 2020. DOI: https://doi.org/10.2307/j.ctv1gm01nn

TANACA, J. J. Aprendizagem expansiva em espaços híbridos de formação continuada de professoras de inglês para crianças no Projeto Londrina Global. 2017. 257f. Dissertation (Ph.D. in Language Studies ) - Universidade Estadual de Londrina, Londrina/PR, 2017.

TONELLI, J. R. A; CRISTOVÃO, V. L. L. O papel dos cursos de Letras na formação de professores de inglês para crianças. Calidoscópio, São Leopoldo/RS, v. 8, n. 1, p. 65-76, 2010. DOI: https://doi.org/10.4013/159. Available at: http:// revistas.unisinos.br/index.php/calidoscopio/article/view/159. Retrieved on: Aug. 19, 2020.

TONELLI, J. R. A; CORDEIRO, G. S. Refletir sobre as línguas para aprendê-las: uma perspectiva de ensino-aprendizagem de inglês por meio de um gênero textual para (na) educação infantil. $M O A R A$, Belém, n. 42, p. 45-63, 2014. DOI: http:// dx.doi.org/10.18542/moara.v0i42.2055. Available at: https://periodicos.ufpa.br/ index.php/moara/article/view/2055. Retrieved on: Aug. 20, 2020.

TONELLI, J. R. A; FERREIRA, O. H. S.; BELO-CORDEIRO, A. E. Remendo novo em vestido velho: uma reflexão sobre os cursos de letras-inglês. REVELLI Revista de Educação, Lingua e Literatura, Inhumas/GO, v. 9, p. 124-141, 2017. Available at: https://www.revista.ueg.br/index.php/revelli/article/view/5666. Retrieved on: August 20, 2020. 
TUTIDA, A. F. Ensino de língua inglesa para crianças: questões sobre formação de professores e os saberes da prática. 2016. 314f. Dissertação (Mestrado em Estudos da Linguagem) - Universidade Estadual de Londrina, Londrina/PR, 2016.

VALÉRIO, K. M.; MATTOS, A. M. A. Critical Literacy and the Communicative Approach: Gaps and Intersections. Revista Brasileira de Linguística Aplicada, Belo Horizonte, v. 18, n. 2, p. 313-338, 2018. DOI: https://doi.org/10.1590/1984-6398201812252

YI, Y.; JANG, J. Envisioning Possibilities Amid the COVID-19 Pandemic: Implications from English Language Teaching in South Korea. TESOL Journal, [S.l.], v. 11, n. 3, p. 1-5, 2020. DOI: https://doi.org/10.1002/tesj.543. Available at: https://onlinelibrary.wiley.com/doi/full/10.1002/tesj.543?af=R. Retrieved on: 20 Aug. 2020.

Data de submissão: 27/10/2020. Data de aprovação: 16/2/2021. 